Henryk KOWALSKI

(Lublin, UMCS)

\title{
PONTIFEX MAXIMUS W RELIGII I PAŃSTWIE RZYMSKIM
}

W państwie rzymskim, już od najdawniejszych czasów, istniały związki między religią a polityką; bez religii państwo rzymskie nie było praktycznie w stanie funkcjonować. Wszystkie czynności publiczne musiały być poprzedzone przepisanymi wróżbami i rytuałami religijnymi, a władze państwowe (senat i urzędnicy) oraz kapłani mieli obowiązek czuwania nad ich prawidłowym przebiegiem ${ }^{1}$.

Podstawową sprawą były przy tym relacje między religią a władzami republiki rzymskiej, między sacrum i publicum ${ }^{2}$. W rzymskim systemie religijnym kapłani nie stanowili w zasadzie odrębnej grupy związanej z funkcjonowaniem świątyń, lecz były to godności sprawowane przez obywateli ${ }^{3}$. Piastowano je $z$ reguły dożywotnio, ale nie wykluczały one (z pewnymi wyjątkami) możliwości obejmowania urzędów państwowych i zasiadania w senacie ${ }^{4}$. Kapłani nie posiadali jakiejś specjalnej władzy politycznej i pełnili raczej funkcje opiniodawczą w sprawach publicznych. Rozstrzygnięcia należały do urzędników posiadających określone imperium, którzy powinni uwzględniać zgłoszone przez kapłanów znaki wróżebne i ich interpretację, oraz zastrzeżenia odnośnie przeprowadzonych obrzędów lub zalecenia dotyczące podjęcia działań przebłagal-

\footnotetext{
${ }^{1}$ Por. A. Wardman, Religion and Statecraft among the Romans, Baltimore 1982, 22.

2 Por. J. Bleicken, Kollisionen zwischen sacrum und publicum, „Hermes” 85 (1957) 446-480.

${ }^{3}$ Na temat kapłanów i ich funkcji w starożytnym Rzymie zob. m.in.: G.J. Szemler, The Priests of the Roman Republic, Bruxelles 1972; D. Porte, Les donneurs de sacré. Le prêtre à Rome, Paris 1989; M. Beard - J. North (ed.), Pagan Priests. Religion and Power in the Ancient World, London 1990 (zwłaszcza: M. Beard, Priesthood in the Roman Republic, 17-48; R. Gordon, From Republic to Principate: priesthood, religion and ideology, 177-198). W j. polskim: J. Scheid, Kapłan, w: Człowiek Rzymu, pod red. A. Giardina, Warszawa 1997, 71-104; H. Kowalski, Kaptani i kolegia kaptańskie w Rzymie w I wieku przed Chrystusem, VoxP 13-15 (1993-1995) z. 24-29, 35-47. Lista kapłanów: J. Rüpke, Fasti sacerdotum. Die Mitglieder der Priesterschaften und das sakrale Funktionspersonal römischer, griechischer, orientalischer und jüdisch-christlicher Kulte in der Stadt Rom von 300 v. Chr. bis 499 n. Chr., Teil 1-2, Stuttgart 2005.

${ }^{4}$ Por. G.J. Szemler, Priesthoods and priestly careers in Ancient Rome, ANRW II 16, 3, Berlin - New York 1986, 2314-2331.
} 
nych $^{5}$. Ostateczne decyzje w wymienionych sprawach podejmował jednak zawsze senat ${ }^{6}$.

Największy zasięg oddziaływania wśród wymienionych kapłanów mieli niewątpliwie pontyfikowie, którzy tworzyli kolegium obradujące pod przewodnictwem pontifeksa maksimusa ${ }^{7}$. Funkcja pontifeksa należała do bardzo zaszczytnych i znaczących $w$ Rzymie, obejmowali ją $z$ reguły przedstawiciele najwybitniejszych rodów patrycjuszowskich, stanowiła też dobrą podstawę do kontynuowania kariery politycznej i osiągania najwyższych stanowisk państwowych $^{8}$. W kwestii genezy terminu pontifex już w starożytności istniało kilka interpretacji. Warron podaje:

„Sacerdotes universi a sacris dicti. Pontufices, ut [a] Sc<a>e-vola Quintus pontufex maximus dicebat, a posse et facere, ut po[n]tifices. Ego a ponte arbitror: nam ab his Sublicius est factus primum ut restitutus $s<a>e p e$, cum ideo sacra et uls et cis Tiberim non mediocri ritu fiant".

Według Kwintusa Mucjusza Scaewoli, znanego prawnika oraz najwyższego kapłana, termin ten wywodził się z połączenia słów: posse i facere. Sam Marek Terencjusz Warron uważał, ze termin ten pochodzi od słowa: pons - most, w tym przypadku od pons Sublicius ${ }^{10}$. Także greccy pisarze Dionizjusz z Halikarnasu oraz Plutarch podają wersję nazwy pochodzącej od terminu pons ${ }^{11}$.

Pontyfikowie czuwali nad przestrzeganiem rytuałów i przepisów sakralnych, zajmowali się formułowaniem modlitw publicznych oraz dokonywali aktów oczyszczających. Mieli przy tym uprawnienia do nakazania powtórzenia obrzędów (instauratio) wraz z ceremoniałem przebłagalnym (piaculum). Niemniej istotne znaczenie miały uprawnienia pontyfików dotyczące kalendarza: określali oni liczbę dni świątecznych oraz zakres czynności, które można było w te dni wykonywać. Wyznaczali także dies comitiales oraz decydowali o wpro-

${ }^{5}$ Por. J. Scheid, Le prêtre et le magistrat. Reflexions sur les sacerdotes et droit public à la fin de la République, w: Des ordres à Rome, ed. C. Nicolet, Paris 1984, 243-280; H. Kowalski, Rola polityczna kapłanów w Rzymie w okresie schyłku Republiki, w: W 2500-lecie powstania Republiki Rzymskiej, pod red. A. Kunisza, Katowice 1995, 31-51.

${ }^{6}$ Por. D. Jost de Treville, Senatus et religio: Aspects of the Roman Senate's Role in the State Religion during the Republic, Diss., Chapel Hill 1987.

${ }_{7}$ Por. F. Van Haepern, Le collège pontifical ( $3^{\text {ème }}$ s. a.C. $-4^{\text {ème }}$ s. p.C.). Contribution à l'étude de la religion publique romaine, Bruxelles - Rome 2002.

${ }^{8}$ Por. D.E. Hahm, Roman nobility and the three major priesthoods (218-167 B.C.), „Transactions and Proceedings of the American Philological Association" 94 (1963) 73-85; Szemler, The Priests, s. 104-137; tenże, Priesthoods, s. 2314n.

${ }^{9} \mathrm{M}$. Varro, De lingua Latina $\mathrm{V} 83,2-3$.

${ }^{10}$ Podobnie gramatyk $z$ IV wieku po Chr. Serwiusz, w komentarzu do Eneidy Wergiliusza II 166: „Ex quo etiam causa Ponifices a ponte sublicio qui primus Tibri impositus est, apellatos tradunt, sicut Saliorum carmina loquuntur".

11 Por. Dionysius Halicarnassensis, Antiquitates Romanae II 73; Plutarchus, Numa 9, 3; zob. szerzej dyskusję: Van Haepern, Le collège pontifical, s. 10n. 
wadzeniu w danym roku dodatkowego miesiąca zwanego intercalarius. Orzekali także o ślubach (vota) oraz w kwestiach rytuału pogrzebowego. Pełnili również funkcję ekspertów religijnych senatu i zgromadzeń ludowych oraz urzędników ${ }^{12}$.

Najbardziej znaczącą funkcją kapłańską w starożytnym Rzymie była godność najwyższego kapłana (pontifex maximus). Liwiusz podaje jego genezę:

„Numa Pompiliusz mianowal następnie pontifeksem maksimusem Numę Marcjusza [...], jednego z senatorów i jemu powierzył szczególowy spis i opis całej służby bożej"13.

Początkowo mianował go król, potem wybierali kapłani-pontyfikowie, lecz już przed 212 r. przed Chr. wprowadzono jego wybór przez 17 tribus wylosowanych spośród 35 wszystkich. W 104 r. przed Chr. na podstawie lex Domitia ustanowiono wybór wszystkich kapłanów przez comitia septemdecim tribuum. System ten usiłował potem obalić Sulla przywracając cooptatio, jednakże w 63 roku przed Chr. lex Labiena ponownie wprowadzila wybór przez 17 tribus $^{14}$.

Podstawowym problemem $w$ literaturze naukowej jest ścisłe określenie jego funkcji i pozycji w państwie. Jest to związane $z$ interpretacją samej nazwy: pontifex maximus. W starszej historiografii pojawia się thumaczenie: najwyższy kapłan ${ }^{15}$. Część wspólczesnych badaczy określa go jedynie jako najwyższego pontifeksa: przewodniczącego kolegium pontifices ${ }^{16}$. Inne najwyższe kompetencje religijne wypełniali: rex sacrorum i flamen Dialis. Były to funkcje, które kontynuowały obowiązki królewskie. W początkowym okresie najważniejszym w strukturze religijnej był prawdopodobnie rex sacrorum (wykluczony $z$ kariery politycznej). Rzymski gramatyk $z$ II wieku po Chr. Pompejusz Festus wymienia następującą kolejność rangi kapłanów w Rzymie:

„Ordo sacerdotum aestimatur deorum [ordine, ut deus] maximus quisque. Maximus videtur Rex, dein Dialis, post hunc Martialis, quarto loco Quirinalis, quinto pontifex maximus" $"$.

${ }^{12}$ Por. Van Haepern, Le collège pontifical, s. 215n.

${ }^{13}$ Livius, Ab urbe condita I 20, thum. A. Kościólek: Liwiusz, Dzieje Rzymu od zatożenia miasta, I, Wrocław 1968, 28.

14 Por. tamże XXV 5, 2; Cicero, De lege agraria 2, 18; zob. L. Ross Taylor, The Election of the Pontifex Maximus in the Late Republic, „Classical Philology” 37 (1942) 421-424; Van Haepern, Le collège pontifical, s. $120 \mathrm{n}$.

is Por. G. Wissowa, Religion und Kultus der Römer, München 1912, 511n.; J. Bleicken, Oberpontifex und Pontifikalkollegium. Eine Studie zur römischen Sakralverfassung, "Hermes” 85 (1957) 345-366.

${ }^{16}$ Por. J. Rüpke, Die Religion der Römer, Eine Einführung, München 2001, 211; J. Champeaux, La religion romaine, Paris 1998, 95; F. Van Haeperen, Grand-prêtre ou hierophante. Les traductions grecques du terme pontifex, „L'Antiquité classique” 73 (2004) 149-163.

${ }^{17}$ Festus, De verborum significatu, ed. A. Lindsay, s. 198-199. 
Dopiero potem wzmocniła się pozycja pontifeksa maksimusa, który przejął kontrolę nad wszystkimi miejscami komunikacji między bogami i ludźmi, a jego funkcja stała się jednocześnie polityczną ${ }^{18}$.

Kompetencje pontifeksa maksimusa dotyczyły zarówno spraw religijnych, jak też i państwowych. Liwiusz we wspomnianym fragmencie określa zakres spraw, jakie powierzył mu Numa Pompiliusz:

,[...].jakie zwierzęta i komu, w których dniach i przy których świątyniach ma się składać w ofierze i skąd brać na nie pieniądze [...]. Do niego mial się udawać lud po poradę, aby przez zaniedbywanie obrzędów ojczystych, a przyjmowanie obcych, nie wkradło się do służby Bożej (divinum ius) jakieś zamieszanie. Zresztą nie tylko ku czci niebian miał uczyć arcykapłan, ale i tego, jak należy urządzać pogrzeby i przebłagania słać duchom zmarłych, jakie znaki cudowne, czy to pioruny, czy inne znaki widzialne, uważać za ważne i jak je zażegnywać (prodigia curare)"19.

Festus podaje następujące rodzaje działalności pontifeksa maksimusa:

„Maximus pontifex dicitur, quod maximus rerum, quae ad sacra et religiones pertinent, iudex sit vindexque contumaciae privatorum magistratuumque"20.

J. Bleicken wymienia następujące urzędnicze uprawnienia przysługujące pontifeksowi maksimusowi:

1). imperium - reprezentował on państwo w sprawach religijnych. Zwoływał i kierował obradami specjalnych zgromadzeń ludowych w sprawach sakralnych (comitia curiata) i testamentowych (comitia calata). Miał również pewne uprawnienia w zakresie prawa cywilnego i karnego. Jego imperium było jednak ograniczone, zabierał głos dopiero na wezwanie konsula.

2). auspicium - prowadził obserwacje znaków zsyłanych przez bogów przed comitia calata, ale nie przysługiwały mu auspicia maxima.

3). potestats - przewodniczyl obradom kolegium pontyfików, których część (rex sacrorum, flamines minores) była przez niego mianowana (captio). Nie podejmował jednak samodzielnych decyzji, które zapadały kolegialnie ${ }^{21}$.

Do zakresu kompetencji pontifeksa maksimusa należał również nadzór nad działalnością kolegium westalek. Miał prawo ich wyboru, a także sądownictwo (iudicium) za przewinienia westalek ${ }^{22}$. Prowadził również zapisy w Annales maximi ${ }^{23}$.

${ }_{18}$ Por. M. Beard - J. North - S. Price, Religions of Rome, vol. 1, Cambridge 1998, 55n.

${ }^{19}$ Livius, $A b$ urbe condita I 20, tłum. A. Kościólek s. 28-29.

${ }^{20}$ Festus, De verborum significatu, ed. Lindsay, s. 113.

21 Por. Bleicken, Oberpontifex, s. 345-366.

22 Por. Van Haepern, Le collège pontifical, s. 96n.

23 Por. Festus, De verborum significatu, ed. Lindsay, s. 113: „Maximi annales appellabantur, non magnitudine, sed quod eos pontifex maximus confecisset”; zob. W. Frier, „Libri Annales Pontificum Maximorum": the Origins of the Annalistic Tradition, Roma 1979. 
Już od początku Republiki funkcja ta ściśle wiązała się z polityką. Stanowisko pontifeksa maksimusa było nie tylko wysoką godnością kapłańską, ale dawało również konkretne wpływy polityczne ${ }^{24}$. Osiągnięcie tej godności było jednym z najważniejszych elementów kariery politycznej. Początkowo mogli je sprawować wyłącznie patrycjusze. Na mocy ustawy Ogulniuszy z 300 r. przed Chr. zostali do kolegium pontyfików dopuszczeni plebejusze ${ }^{25}$. W 254 roku przed Chr. Tyberiusz Coruncanius osiągnął jako pierwszy z plebejuszy godność pontifeksa maksimusa ${ }^{26}$. W 132 r. przed Chr. pontifeks maksimus Publiusz Kornelius Scypion Nazyka dokonując, jak udowodnił J. Linderski, consecratio capitis, ogłosił Tyberiusza Grakcha jako homo sacer doprowadzając do ucieczki jego zwolenników i śmierci trybuna 27 .

Z I wieku przed Chr., z okresu przed Augustem, znanych jest pięciu najwyższych kapłanów: Gnejusz Domicjusz Ahenobarbus (ok. 103-89), Kwintus Mucjusz Scewola (ok. 89-82), Kwintus Cecyliusz Metellus Pius (81-63), Gajus Juliusz Cezar (63-44), Marek Emiliusz Lepidus (44-12) ${ }^{28}$. Wydatny wzrost znaczenia politycznego najwyższego kapłana nastąpił w Rzymie za pontyfikatu Kwintusa Mucjusza Scewoli (89-82). Zasłynął on również jako wybitny filozof i prawnik, zwłaszcza w zakresie prawa sakralnego ${ }^{29}$. W okresie I wojny domowej w Rzymie włączył się aktywnie w wir wydarzeń politycznych, opowiadając się po stronie Sulli. Stało się to zresztą powodem jego śmierci, gdyż w 82 r. zamordowali go zwolennicy młodego Mariusza. Charakterystyczne, iż wydarzyło się to mimo piastowania przez Mucjusza Scewolę najwyższej funkcji sakralnej $^{30}$. Następca Scewoli - Kwintus Cecyliusz Metellus Pius nie odegrał szczególnie znaczącej roli politycznej ${ }^{31}$.

Nowe aspekty do funkcjonowania i znaczenia godności najwyższego kapłana wprowadził Cezar ${ }^{32}$. W 63 r. przed Chr. rozpoczął starania o to stanowisko, mimo iż swoje kandydatury zgłosili również dwaj zasłużeni politycy i kapłani:

${ }^{24}$ Por. A. Heltweg, Die politische Bedeutung der römischen Oberpontifikates, Diss., Köln 1952.

25 Por. Rüpke, Fasti sacerdotum, Teil 2, 1621n.

${ }^{26}$ Por. Livius, Periochae 18: „T. Coruncanius primus ex plebe pontifex maximus creatus est”; zob. Szemler, The Priests, s. 78; Rüpke, Fasti sacerdotum, Teil 1,61.

27 Por. J. Linderski, Śmierć Tyberiusza Grakcha, Poznań 1997, 5n.

28 Por. Szemler, The Priests, ss. 124, 129, 131-132, 134; Rüpke, Fasti sacerdotum, Teil 2, 947; $1159 ; 833 ; 1057-1059 ; 737-738$.

${ }^{29}$ Por. G. Lepointe, Q. Mucius Scaevola, I: Sa vie et son oeuvre juridique. Ses doctrines sur le droit pontifical, Paris 1926; O. Behrends, Die Wissenschaftslehre im Zivilrecht des Q. Mucius Scaevola Pontifex, Göttingen 1976.

${ }^{30}$ Por. Appianus, Bella civilia I 88; Florus, Epitome II 9, 13; Valerius Maximus, Factorum dictorum memorabilium IX 11, 2.

31 Por. Szemler, The Priests, s. 129; Rüpke, Fasti sacerdotum, Teil 2, 833.

32 Por. R. Stepper, Der Oberpontifikat von Caesar bis Nerva. Zwischen Tradition und Innovation, w: C. Bartsch - U. Egelhaaf-Gaiser - R. Stepper (Hgg.), Zwischen Krise und Alltag. Antike Religionen im Mittelmeerraum, Stuttgart 1999, 171-185. 
Kwintus Lutacjusz Katulus (konsul z 78 r. oraz cenzor z 65 r.) i P. Serwiliusz Watia Izaurykus (konsul z 79 r.). Jak podają Plutarch, Swetoniusz i Kasjusz Dion, postanowił on osiągnąć najwyższy pontyfikat za wszelką cenę, przede wszystkim za pomocą przekupstw wyborczych. Swetoniusz dodaje przy tym, iż Cezar potraktował te wybory tak prestiziowo, ze wychodzac $z$ domu na zgromadzenie, miał powiedzieć matce: „domum se nisi pontificem non reversurum"33. Cezar już od młodych lat zdawał sobie sprawę $\mathrm{z}$ roli funkcji kapłańskich w działalności politycznej. W 87 r. przed Chr. został on mianowany kapłanem Jowisza (flamen Dialis), w 73 r. przed Chr. wszedł do kolegium pontyfików na miejsce swego wuja M. Aureliusza Kotty ${ }^{34}$.

Cezar przywiązywał bardzo dużą wagę do funkcji najwyższego kapłana. Stanowisko to było $\mathrm{mu}$ wielce pomocne $\mathrm{w}$ realizowaniu celów politycznych: osiągnięcia najwyższej władzy w państwie, a w późniejszym okresie także ubóstwienia $^{35}$. Jak podaje Swetoniusz, w 62 roku przed Chr. uchroniło go ono przed działaniami senatu, który siłą chcial pozbawić go funkcji pretora: Cezar odesłał liktorów, zrzucił urzędniczą togę (toga praetexta) i schronił się w swym mieszkaniu, gdzie jako pontifex maximus był nietykalny ${ }^{36}$. Przydatne okazało się również ono w jego działaniach politycznych już w okresie konsulatu w 59 r. przed Chr. Wykorzystal go m.in. przy przeprowadzeniu adoptio Publiusza Klodiusza, a także w działaniach przeciwko drugiemu konsulowi M. Kalpurniuszowi Bibulusowi, który próbował zastosować obstrukcję religijną, przez ogłaszanie obserwacji nieba ${ }^{37}$.

Szczególnego znaczenia funkcja ta nabrała jednak w okresie II wojny domowej i dyktatury Cezara. Postanowił on wówczas rozszerzyć swoje kompetencje w zakresie religijnym. W 47 roku przed Chr. Cezar został wybrany augurem. W ten sposób uzyskał dodatkowe uprawnienia do prowadzenia auspicjów. Symbolem tego stały się monety wydawane przez Cezara, na których pojawia się zakrzywiona laska auguralna - lituus ${ }^{38}$. Część badaczy interpretuje to nie tylko jako oznakę auguratu, ale także najwyższe imperium polityczne oraz zwierzchnictwo religijne jako pontifeksa maksimusa ${ }^{39}$. Znalazło to odzwierciedlenie w propagandzie politycznej Cezara, w której stanowisko pontifeksa maksimusa podkreślało jego wyjątkową pozycję jako czlowieka, który osiągnął najwyższe godności i zaszczyty, dające mu władzę polityczną i religijną.

${ }^{33}$ Por. Plutarchus, Caesar 7; Suetonius, Caesar 13; Cassius Dio, Historia Romana XXXVII 37.

34 Por. L. Ross Taylor, Caesar's Early Career, „Classical Philology” 36 (1941) 113-132.

35 Por. G. Huber, Untersuchungen zu Caesars Oberpontifikat, Diss., Tübingen 1971; S. Weinstock, Divus Iulius, Oxford 1971, 28n.

${ }^{36}$ Por. Suetonius, Caesar 16.

${ }^{37}$ Por. Huber, Untersuchungen, s. 58n.

38 Por. M. Crawford, Roman Republicain Coins, vol. 1, Cambridge 1974, No. 456/1a-b; 466/1; 467/1; 467a-b.

39 Por. L. Morawiecki, Symbole urzędów religijnych na monetach republiki rzymskiej, w: Religie w świecie starożytnym, pod red. D. Musiał - M. Ziołkowskiego, Toruń 1993, 72-79. 
Na monetach Cezara $\mathrm{z}$ tego okresu znalazły się symbole religijne związane z wykonywanymi funkcjami kapłańskimi: szpiczasta czapka kapłańska (apex), topór (securis), kropidło (aspergillum), czerpak (simpulum), zakrzywiona laska auguralna (lituus), rytualne naczynie (capis) oraz legendy AVGVR PONT MAX. W latach 49-48 wybito denary Cezara, na których znalazły się symbole religijne związane $\mathrm{z}$ urzędami kapłańskimi: apex, securis, aspergillum, simpulum. Znaki te, a także następne symbole (lituus $i$ capis) pojawiają się również na aureusach z 47 r. (z legendą: CAESAR DICT ITER), aureusach Aulusa Hircjusza z 46 r. (z legendą: A HIRTIUS PR, C CAESAR COS TER) oraz denarach Cezara z 46 r. (z legendą: COS TERT DICT ITER, AVGVR PONT MAX). L. Morawiecki wysunął hipotezę, iż kumulację tych symboli można interpretować nie jako przedstawienie poszczególnych funkcji kapłańskich, ale jako zapowiedź wyjątkowej pozycji religijnej Cezara ${ }^{40}$.

W napisach poświęconych Cezarowi, pochodzących z terenu Grecji, zwłaszcza po bitwie pod Farsalos, podkreśla się związki jego władzy politycznej i religijnej w oznaczeniach: imperator - pontifex maximus (archiereus), przy czym drugi tytuł zastępowany jest też określeniem theos - „bóg”41. Także w inskrypcjach italskich poświęconych Cezarowi podkreślane są związki jego władzy politycznej i religijnej, pojawiają się zestawienia: imperator - pontifex maximus - parens patriae ${ }^{42}$. L. Ross Taylor sugeruje, iż pontyfikat Cezara był jednym z etapów kwalifikujących go „to divine rulership”, E. Taeger uważa go za początek kształtowania władzy charyzmatycznej dyktatora ${ }^{43}$.

Śmierć Cezara i kolejne wojny zapoczątkowały nowy etap dziejów Rzymu. Efektem było wprowadzenie nowego ustroju - pryncypatu. Początkowo funkcja pontifeksa maksimusa, za wsparciem Antoniusza przypadła poźniejszemu triumwirowi Markowi Emiliuszowi Lepidusowi, który początkowo próbował nawiązywać do tradycji cezariańskiej. Na monetach z 43 r. przed Chr. pojawiają się: apex, aspergillum, simpulum, securis ${ }^{44}$. Przegrana w wojnie peruzyńskiej zmieniła jednak pozycję Lepidusa, który odtąd traktował funkcję pontifeksa maksimusa jako zaszczyt.

${ }^{40}$ Por. Crawford, Roman Republicain Coins, No. 443/1; 456/1a-b; 466/1; 467/1a-b. Na temat interpretacji tych monet zob. A. Alföldi, The Main Aspects of Political Propaganda on Coinage of the Roman Republic, w: Essays in Roman Coinage Presented to Harold Mattingly, ed. R.A.G. Carson - C.H.V. Sutherland, Oxford 1956, 63-95; Morawiecki, Symbole urzędów religijnych, s. $72-79$.

41 Por. A. Raubitschek, Epigraphical notes on Julius Caesar, „Journal of Roman Studies” 44 (1954) 65-75.

${ }^{42}$ Por. Stepper, Der Oberpontifikat, s. 174n.

43 Por. L. Ross Taylor, The Divinity of the Roman Emperor, Moddleton 1931, 59n.; F. Taeger, Charisma, Bd. 2, Stuttgart 1960, 124n.; Weinstock, Divus Iulius, s. 31n.

44 Por. Crawford, Roman Republicain Coins, No. 489/1-3; zob. L. Morawiecki, Political Propaganda in the Coinage of the Late Roman Republic, Wrocław - Warszawa - Kraków 1983,77n. 
Charakterystyczne było, że mimo jego klęski militarnej Oktawian nie pozbawił go stanowiska, także po zakończeniu wojny z Antoniuszem ${ }^{45}$. Nie było to rezultatem lekceważenia przez Augusta tej funkcji religijnej i jej znaczenia; Lepidus prawdopodobnie był tylko nominalnym kapłanem, kontrolowanym przez Augusta. Na monetach Oktawiana wybitych w 37 r. przed Chr. pojawiają się te same symbole urzędów kapłańskich, co na wspomnianych monetach Cezara: simpulum, aspergillum, capis i lituus ${ }^{46}$. L. Morawiecki interpretuje to jako nawiązanie do tradycji Cezara oraz roszczenia do urzędu pontifeksa maksimusa $^{47}$. W 29 r. przed Chr. przy zamknięciu bramy Janusa augurium salutis odbyło się z udziałem kolegium augurów, ale bez Lepidusa. Podobnie w 17 r. przed Chr. urządził ludi saeculares bez konsultacji z pontyfikami, ale $X V$-viri sacris faciundis ${ }^{48}$.

Nawiązaniem do tych działań są reliefy z Ołtarza Pokoju (Ara Pacis) Augusta. W rytualnej procesji biorą udzial członkowie najwyższych kolegiów kapłańskich. Princeps jest przedstawiony obok flaminów, ale wyróżnia się togą zarzuconą na głowę. W literaturze pojawiają się różne interpretacje tej procesji. P. Zanker uznaje to za symbolikę odwolującą się do stanowiska najwyższego kapłana $^{49}$. G.W. Bowersock uważa, że płaskorzeźby te odnoszą się do supplicationes z okazji objęcia przez Augusta funkcji najwyższego kapłana, inni, że są to supplicationes z $13 \mathrm{r}$. przed Chrystusem ${ }^{50}$.

W 12 r. przed Chr., po śmierci Lepidusa, pontifeksem maksimusem zostaje wybrany August. W Res gestae divi Augusti podaje on, że z całej Italii napłynęły wówczas niezliczone tłumy, by wziąć udział w zgromadzeniu ${ }^{51}$. Już dwa miesiące później dedykował świątynię Westy z napisem: Imp. Caes. Aug. Pont.max. ${ }^{52}$. Od tego momentu władza religijna zostaje całkowicie połączona z władzą polityczną. August przekształca tę funkcję w rzeczywiste stanowisko najwyższego kapłana, ,głowy religii rzymskiej”. Charakterystyczne jest przy tym lączenie funkcji kaplańskich przez Augusta. W Res gestae divi Augusti cesarz pisał:

45 Por. Res gestae divi Augusti 10.

46 Por. Crawford, Roman Republicain Coins, No. 537/1; 538/1.

47 Por. L. Morawiecki, Wtadza charyzmatyczna w Rzymie u schytku Republiki 44-27 p.n.e., Rzeszów 1989, 230; tenże, Symbole urz̨̧dów religijnych, s. 77.

${ }^{48}$ Por. R. Stepper, Augustus et sacerdos. Untersuchungen zum römischen Kaiser als Priester, Stuttgart 2003, 112n.

${ }_{49}$ Por. P. Zanker, August i potęga obrazów, Poznań 1999, s. 127n.

${ }^{50}$ Por. G.W. Bowersock, The Pontificate of Augustus, w: Between republic and Empire. Interpretations of Augustus and his Principate, hrsg. von K.A. Raaflaub - M. Toher, Berkeley Los Angeles - Oxford 1990, 380-394; R. Billows, The religious procession of the Ara Pacis Augus. tae: Augustus' supplicatio in 13 B.C., ,Journal of Roman Archaeology” 6 (1993) 80-92.

51 Por. Res gestae divi Augusti 10.

52 Por. J. Scheid, Auguste et le grand pontificat. Politique et droit sacré au début du Principat, „Revue Historique de Droit" 77 (1999) 1-19. 
„Byłem najwyższym kapłanem, pontifeksem (48 r. przed Chr.), augurem (41-40), czlonkiem kolegium: $X V$-viri sacris faciundis, (ok. 37) kolegium: septemviri epulones, (16), członkiem: fetiales, sodales Titii, Fratres Arvales ${ }^{53}$.

W ten sposób August zapoczątkował skupianie w ręku princepsa wszelkich kompetencji przysługujących kapłanom, czlonkom najważniejszych kolegiów, a funkcja pontifeksa maksimusa połączona została $\mathrm{z}$ realną władzą religijną ${ }^{54}$. $\mathrm{Na}$ podkreślenie zasługuje też fakt, że od czasów Augusta jednym z podstawowych działań pontifeksa maksimusa staje się jego funkcja ofiarna. Posągi, płaskorzeźby i monety ukazują go jako kapłana odzianego $w$ togę $z$ nakrytą glową jako ofiarnika $^{55}$. August powiązal je również z licznymi reformami religijnymi, przywracającymi m.in. stare kulty. Całkiem nową działalnością była reforma przewidująca dzielenie miasta na XIV regionów i 265 vici, związanych z Lares Compitales. Jednocześnie najwyższy pontyfikat był kontynuacją linii zapoczątkowanej przez Cezara. W 2 r. przed Chr. August otrzymuje tytul pater patriae, co w dalszej perspektywie stawało się jednym z czynników prowadzących do deifikacji ${ }^{56}$.

Zmiany zapoczątkowane przez Augusta kontynuowali później następni cesarze. Tyberiusz przyjmuje tytuł pontifeksa maksimusa od 10 marca $15 \mathbf{r}$. po Chrystusie ${ }^{57}$. Podobnie jak August skumulowal on w swym ręku kompetencje religijne przynależne członkom najwyższych kolegiów kapłańskich ${ }^{58}$. Przeprowadził on dalsze reformy dotyczące kolegiów kapłańskich. Funkcja kapłana Jowisza (flamen Dialis) stała się dziedziczna z ojca na syna. Zezwolił też na dłuższą niż dotychczas jego nieobecność w Rzymie („dłużej niż dwie noce, tylko nie w dniach ofiary publicznej i nie częściej jak dwa razy do roku"). Zmienił też prawne ograniczenia dotyczące flaminica Dialis ${ }^{59}$.

Podobną funkcję sprawował Kaligula. Jeszcze przed sukcesją po Tyberiuszu byl: sodalis Augustalis, sodalis Titius, frater arvalis i fetialis. W 31 r. po Chr. został pontyfikiem, a przed 37 r. po Chr. augurem. Funkcję pontifeksa maksimusa osiągnął 18 marca 37 r. po Chrystusie ${ }^{60}$.

$\mathrm{Z}$ czasem łączenie najważniejszych funkcji kapłańskich stało się jednym $\mathrm{z}$ elementów przygotowań do sukcesji pryncypatu. Jednocześnie wraz z przejęciem władzy państwowej cesarz zostawał najwyższym kapłanem ${ }^{61}$. Po adopcji Nerona przez Klaudiusza w 50 r. po Chr. zostaje on przyjęty do quattuor amplissima collegia (pontyfików, augurów, $X V$-viri sacris faciundis oraz

\footnotetext{
${ }^{53}$ Res gestae divi Augusti 7.

${ }^{54}$ Por. Beard - North - Price, Religions of Rome, s. $191 \mathrm{n}$.

${ }^{55}$ Por. Zanker, August, s. 133 n.

56 Por. I. Gradel, Emperor Worship and Roman Religion, Oxford 2002, 109n., 261n.

57 Por. Stepper, Der Oberpontificat, s. 181n.

58 Por. Stepper, Augustus, s. 45n.

59 Por. Tacitus, Annales III 71, 2.

60 Por. Stepper, Augustus, s. $47 \mathrm{n}$.

61 Por. Van Haepern, Le collège pontifical, s. 131-132 (tabela).
} 
VII-viri epulones). Na aureusie Nerona pojawiają się symbole: Lituus (oznaka augura), simpulum (symbol pontifices), trójnóg do libacji i ofiar - symbol $X V$-viri sacris faciundis oraz patera - czara libacyjna, symbol septemviri epulones i napis: „Sacerd (os) Coopt (atus) In Omn (ia) Conl (egia) Supra Num (erum) Ex S (enatus) C (onsulto) ${ }^{, 62}$.

Kontynuację polityki w tym zakresie prowadzili następcy dynastii julijskoklaudyjskiej ${ }^{63}$. Galba za zasługi w Afryce i Germanii adoptowany do 3 kolegiów. ( $X V$-viri, sodales Titii, sodales Augustales Claudiales), a po wyborze na cesarza przyjął tytuł najwyższego kapłana ${ }^{64}$. Oton od 57 r. po Chr. był członkiem kolegium Fratres Arvales, a 9 marca 69 r. po Chr. przyjął tytuł: pontifex maximus $^{65}$. Witeliusz po zwycięstwie nad Otonem i przybyciu do Rzymu 18 lipca 69 r. również przyjmuje tytuł pontifeksa maksimusa ${ }^{66}$. Wespazjan przed dies imperii był członkiem dwóch kolegiów. Funkcję pontifeksa maksimusa objął w 70 r. po Chrystusie ${ }^{67}$. Jego następcy: Tytus i Domicjan jeszcze za panowania ojca zostali wybrani do najwyższych kolegiów ${ }^{68}$.

Charakterystyczna jest również tytulatura cesarza Nerwy, który w dies imperii (18 września 96 r. po Chr.) przyjął obok tytułów imperatora, Cezara, Augusta i pater patriae oraz prerogatyw władzy państwowej: imperium proconsulare i tribunicia potestas także stanowisko: pontifex maximus ${ }^{69}$. System kooptacji do najwyższych kolegiów w połaczeniu $z$ tytułem pontifeksa maksimusa utrzymał się aż do IV wieku po Chrystusie ${ }^{70}$.

Rozszerzone zostały również kompetencje najwyższego kapłana: decretum pontificum, arrogatio (przy adopcji), captio, kontrola nad pogrzebami itd., zwierzchnictwo nad westalkami. Jedną z podstawowych funkcji były ofiary. $\mathrm{Na}$ łuku Trajana w Beneventum z 114 po Chr. występuje on jako pontifex maximus $\mathrm{w}$ scenie ofiarnej $\mathrm{w}$ todze $\mathrm{i}$ capite velato. Podobnie na kolumnie Trajan przedstawiony jest podczas składania ofiary $z$ nakrytą głową ${ }^{71}$. W III wieku cesarze zaczęli występować także jako kapłani innych kultów np. Heliogabal jako najwyższy kapłan syryjskiego boga Elagabala ${ }^{72}$.

${ }^{62}$ H. Mattingly - E.A. Sydenham - C.H.V Sutherland (ed.), The Roman Imperial Coinage, vol. 1, London 1923, No 95-99; por. M.W. Hoffman-Lewis, The Official Priests of Rome under the Julio-Claudians. A Study of the Nobility from 44 B.C. to 68 A.D., Rome 1955, 134.

63 Por. L. Schumacher, Die vier hohen römischen Priesterkollegien unter den Flavier, den Antonine und den Severern (69-235 n.Chr.), ANRW II 16, 1, s. 655-819.

${ }^{64}$ Por. Suetonius, Galba 8; zob. Stepper, Augustus, s. 53n.

65 Por. Schumacher, Priesterkollegien, s. 738-739.

${ }^{66}$ Por. Suetonius, Vitelius 11; zob. Van Haepern, Le collège pontifical, s. 137-147.

${ }^{67}$ Por. Stepper, Augustus, s. 58n.

68 Por. tamże 61 n; zob. Van Haepern, Le collège pontifical, s. 131.

${ }^{69}$ Por. Stepper, Augustus, s. 63n.

${ }^{70}$ Por. Van Haepern, Le collège pontifical, s. $148 \mathrm{n}$.

${ }^{71}$ Por. Stepper, Augustus, s. 160.

72 Por. Herodianus, Ab excessu divi Marci V 5, 5-7. 
Po przyjęciu chrześcijaństwa cesarze nadal używali tytulatury pontifex maximus. Prowadziło to do pewnego konfliktu między funkcją a wiarą chrześcijańską ${ }^{73}$. Konstantyn jako najwyższy kapłan wydał dekret przeciw magii i wróżbom oraz krwawym ofiarom ${ }^{74}$. Konstancjusz II na mocy uprawnień pontifeksa maksimusa przeprowadził ustawodawstwo przeciwko niszczeniu grobów ${ }^{75}$.

Dla Juliana Apostaty przyjęcie tytułu pontifeksa maksimusa stanowiło podstawę dla jego działań, zmierzających do przywrócenia rangi kultom pogańskim. W tym celu przeprowadził reformy dotyczące kapłaństwa, które miały na celu wprowadzenie jednolitej struktury kapłanów, związanych $z$ dawnymi kultami ${ }^{76}$. Już wcześniej uwypuklał znaczenie funkcji kapłańskich w działalności cesarzy ${ }^{77}$. W listach podkreślał znaczenie swojej funkcji najwyższego kapłana, domagając się posłuszeństwa od mianowanych przez siebie arcykapłanów ${ }^{78}$. Własnoręcznie dokonywał ofiar krwawych, co było nawiązaniem do swoich poprzedników $z$ czasów pryncypatu ${ }^{79}$. Jego następcy mimo rezygnacji $\mathrm{z}$ reform Juliana dalej używali tego tytułu.

Dopiero cesarz Gracjan zrezygnowal $z$ tego tytułu ${ }^{80}$. Sprawą dyskusyjną jest data oraz powody rezygnacji. Większość badaczy przyjmuje, że miało to miejsce miedzy 379 a 382 r. po Chrystusie ${ }^{81}$. R. Stepper twierdzi, że na Gracjana miał wpływ św. Ambroży z Mediolanu i łączy to ze sprawą posągu Wiktorii oraz dekretu dotyczącego westalek. Określa go jako symboliczny gest Gracjana $z$ jego „,antiheidnischen Massnahmen”82. W 379 r. Teodozjusz nie przyjął oficjalnie tytułu pontifex maximus ${ }^{83}$.

Tytuł ten zostaje zaadoptowany przez chrześcijan. Charakterystyczne jest, że już Tertulian użył terminu pontifex w odniesieniu do biskupów: „Pontifex scilicet maximus, quod <est> episcopus episcoporum, edicit" ${ }^{, 44}$. W tekście synodu z 378 r. pojawia się: pontifex religionis ${ }^{85}$. Tytulatura ta przeszła na papie-

73 Por. A. Marcone, Pagano e cristiano. Vita e mito di Costantino, Roma - Bari 2002.

74 Por. P.P. Onida, Il divieto dei sacrifici di animali nelle legislazione di Constantino. Una interpretazione sistematica, „Diritto \& Storia” no. 2, Marzo 2003, s. 1.77 (wersja elektroniczna).

${ }^{75}$ Por. Stepper, Augustus, s. 197-201.

76 Por. Sz. Olszaniec, Julian Apostata jako reformator religijny, Kraków 1999, 106n.

77 Por. Iulianus, Orationes II 68B i 90 A.

${ }^{78}$ Por. Iulianus, Epistulae 88: „jestem wielkim arcykapłanem”; 89b: „stał się kapłanem najwyższym nie bez woli bogów".

79 Por. Olszaniec, Julian Apostata, s. 45n.

80 Por. Zosimos, Historia nova IV 36, 3-4.

81 Por. dyskusję: Van Haepern, Le collège pontifical, s. 161n.

82 Por. Stepper, Augustus, s. 216n

${ }^{83}$ Por. tamże, s. 222n.

84 Tertullianus, De pudicitia I 6, CCL 2, 1281-1282. Szerzej o funkcji pontifeksa maximusa w literaturze wczesnochrześcijanskiej zob. F Van Haepern, Perceptions chrétiennes du pontificat païen ( fin $2^{\grave{e} m e}$ s. $-5^{\grave{m} m e}$ s.), „Folia Electronica Classica” 2, julliet - dicembre 2001, 1-71 (wersja elektroniczna).

${ }^{85}$ Por. P. Stockmeier, Die Ubernahme des Pontifex-Titels im spätantiken Christentum, w: 
ży. W Kodeksie Teodozjańskim papież Damazy (366-384) określony jest jako pontifex $^{86}$. Także papieże: Bonifacjusz (418-422) oraz Celestyn (422-432) używali tytułu summus pontificus ${ }^{87}$. W jednym $\mathrm{z}$ listów Paulina $\mathrm{z}$ Noli termin summus pontifex użyty jest na określenie św. Augustyna ${ }^{88}$. Papież Leon Wielki (440-461) używał prawdopodobnie tytułu pontifex maximus ${ }^{89}$.

Tytuł pontifex występuje jednak także przy aklamacjach cesarzy. Sprzeciwił się temu papież Gelazy (492-496), który w czasach cesarza Anastazjusza pisał:

„Quod in suis quoque diabolus imitatus est, utpote qui semper quae divino cultui convenirent sibimet tyrranico spiritu vindicare contendit, ut pagani imperatores iidem et Maximi Pontifices dicerentur. Sed quum ad verum ventum est eundem regem atque pontificem, ultra sibi nec imperator pontificis nomen imposuit, nec pontifex regale fastigium vindicavit" 90 .

Podsumowując należy stwierdzić, że funkcja pontifeksa maksimusa zmieniała się wraz z rozwojem państwa i imperium rzymskiego. Niewątpliwie już od samego początku należała do najbardziej zaszczytnych. Pontifex maximus posiadał znaczne prerogatywy religijne, ograniczone jednak początkowo przez innych kapłanów oraz urzędników i senat. Wzrost znaczenia nastąpił wraz $\mathrm{z}$ upolitycznieniem tego stanowiska, co znakomicie wykorzystał Cezar do utrwalenia swojej władzy. Jednocześnie kompetencje religijne i kumulacja funkcji kapłańskich stały się jedną z oznak jego władzy charyzmatycznej, stanowiącej bazę dla przyszłej deifikacji. Kierunek tych przemian utrwalił cesarz August. Od jego czasów funkcja pontifeksa maksimusa jako najwyższego kapłana staje się jedną z podstaw (obok imperium maius i tribunicia potestas) władzy princepsa. Charakterystyczne jest przy tym jej połączenie $z$ członkostwem we wszystkich najważniejszych kolegiach kapłańskich, co dawało praktycznie nie-

Konzil und Papst. Historische Beiträge zur Frage der höchsten Gewalt in der Kirche, Festgabe für Hermann Tüchle, hrsg. von G. Schweiger, München - Padeborn - Wien 1975, 75-84.

86 Por. Codex Theodosianus XVI 1, 2 (pod datą 27 lutego 380 r.): „Imppp. gratianus, valentinianus et theodosius aaa. edictum ad populum urbis constantinopolitanae. cunctos populos, quos clementiae nostrae regit temperamentum, in tali volumus religione versari, quam divinum petrum apostolum tradidisse romanis religio usque ad nunc ab ipso insinuata declarat quamque pontificem damasum sequi claret et petrum alexandriae episcopum virum apostolicae sanctitatis, hoc est, ut secundum apostolicam disciplinam evangelicamque doctrinam patris et filii et spiritus sancti unam deitatem sub parili maiestate et sub pia trinitate credamus".

87 Por. I. Kajano, Pontifex maximus as Title of the Pope, „Arctos” 15 (1981) 37-52.

88 Por. Paulinus Nolanus, Epistula 7,3 (ad Romanianum), PL 61, 180: „Tunc vere sibi summus Christi pontifex Augustinus"; zob. Stockmeier, Die Ubernahme, s. 80.

89 Pojawia się on m.in. na mozaice Galli Pacydii, por. R. Schieffer, Der Papst als Pontifex Maximus, „Zeitschrift der Savigny Stiftung für Rechtsgeschichte. Kanonistische Abteilung" 57 (1971) 300-309.

${ }^{90}$ Gelasius, Tractatus IV 11, ed. A. Thiel: Epistolae Romanorum Pontificum genuinae, Brunsbergae 1868, 567; por. G. Dragon, Empereur et prêtre. Étude sur le „césaropapisme” byzantin, Paris $1996,190-191$ i $309 n$. 
ograniczony nadzór nad wszelkimi sprawami religijnymi, a jednocześnie wzmacniało władze polityczną. Rozpowszechnienie chrześcijaństwa w IV wieku nie przyniosło początkowo zmian, cesarze nadal używali tej tytulatury. Dopiero od czasów Gracjana i Teodozjusza tytuł pontifeksa zaczyna przechodzić stopniowo na papieży.

\section{PONTIFEX MAXIMUS IN ROMAN'S RELIGION AND STATE}

(Summary)

The function of pontifex maksimus belonged to the most important posts in Roman's religion and state. Roman tradition attributed its establishment to the second king: Numa Pompilius. The name itself, is probably derived from two words: pons and facere. According to modern scientists, at the beginning, he was only a chairman of the college of pontifices, with time this post had more religious and political meaning.

Pontifex maximus had great religious prerogatives, however, it was limited, at the beginning, by other priests, officials and senate. The importance of this post grew with its politicization. This fact was used by Caesar to strengthen his power. At the same time, religious competences and accumulation of priest's functions became one of the signs of its charismatic power that formed basis for future deification.

Direction of those changes was perpetuated be Caesar August. Since his times, the function of pontifex maximus as the highest priest, has become one of the foundations (besides imperium maius and tribunicia potestas) of the power of princeps. The fact that it was joined with the membership in all most important priests'colleges, gave it, in fact, unlimited supervision over all religious matters and, at the same time, it strengthened the political power. The spread of Christianity in the IV century AD didn't bring any changes at the beginning, emperors still used these titles. The title of pontifex has been gradually used by Popes since emperors: Gracianus and Theodosius. 